
IP Periodica Polytechnica
Civil Engineering

61 (4), pp. 752-761, 2017

https://doi.org/10.3311/PPci.10530

Creative Commons Attribution (i)

RESEARCH ARTICLE

\section{Morphological Investigation of a Critical Reach of the Upper Hungarian Danube}

\author{
Gergely T. Török ${ }^{1,2, *}$, Sándor Baranya ${ }^{2}$
}

Received 23 January 2017; Accepted 10 February 2017

\begin{abstract}
The aim of this study is to analyze the current morphological changes and to predict the potential future trends of a critical reach of the upper Hungarian Danube River. In this section of the river the morphological features have undergone significant changes, mainly due to human impacts, such as the construction of the Gabcikovo hydropower plant close to the Slovakian border, or the river regulation measures with groin fields along the Hungarian reach. The morphological changes of the river inherently led to river management issues, e.g. the developed gravel bars caused problems for inland navigation. In order to reveal and understand the characteristic morphodynamic processes, results from past bed geometry surveys were assessed, moreover, extensive field measurement campaigns were carried out, including bathymetry survey, flow survey with fixed and moving Acoustic Doppler Current Profiler (ADCP), bed material sampling and bedload measurements. The utilization of up-to-date field data processing methods provided essential information on the current dominant morphological processes and finally, suggestions were made on the stability of the river planform.
\end{abstract}

\section{Keywords \\ river morphology, upper Hungarian Danube River, bed armoring}

\section{Introduction}

The knowledge of spatial and temporal variation of river morphology can be essential for river users, especially if the river is exposed to multiple use, such as the Danube River. The Danube River is the second largest river in Europe and has the most international river basin shared by 19 countries. The river is used for many purposes, such as inland navigation, energy production, drinking water supply, natural habitat, which led to the regulation of the river and the construction of different engineering structures all along the river from the source to the estuary. Contrarily to the reach upstream of Hungary, where the river is almost entirely regulated by barrages, the $417 \mathrm{~km}$ long Hungarian section is free flowing. However, the river is regulated with conventional structures, such as groynes and the banks are protected against erosion by ripraps. Historically, the $\sim 100 \mathrm{~km}$ long upper Hungarian Danube reach, shared by Slovakia, permanently showed morphological changes and consequent issues for navigation. The morphological variation became even more problematic when the hydropower plant at Gabcikovo, Slovakia had been constructed $8 \mathrm{~km}$ upstream from the Hungarian border. This study focuses on a Danube reach situated between Nagybajcs and Gönyű (rkm 1796 - 1799), $20 \mathrm{~km}$ downstream of Gabcikovo hydroelectric power plant (rkm 1819), and immediately upstream of the Mosoni-Danube confluence zone (Fig. 1 and Fig. 2). The human measures, described later on, caused major changes in the morphological processes, which resulted in several effects, e.g. gravel bar formation in the main channel [1]. This phenomenon can be clearly observed in the study site at Gönyü [2], where the so called Vének ford [3] formed and caused increasing difficulties for navigation, since the adequate water depth for the ships is not ensured at low flow regime at such locations. Apparently, these problems related to the morphological changes require the knowledge of both the local and larger scale morphological processes.
${ }^{1}$ MTA-BME Water Management Research Group,

H-1111 Budapest, Müegyetem rkp. 3., Hungary

${ }^{2}$ Department of Hydraulic and Water Resources Engineering,

Faculty of Civil Engineering,

Budapest University of Techology and Economics

H-1111 Budapest, Mủegyetem rkp. 3., Hungary

${ }^{*}$ Corresponding author, email: torok.gergely@epito.bme.hu 


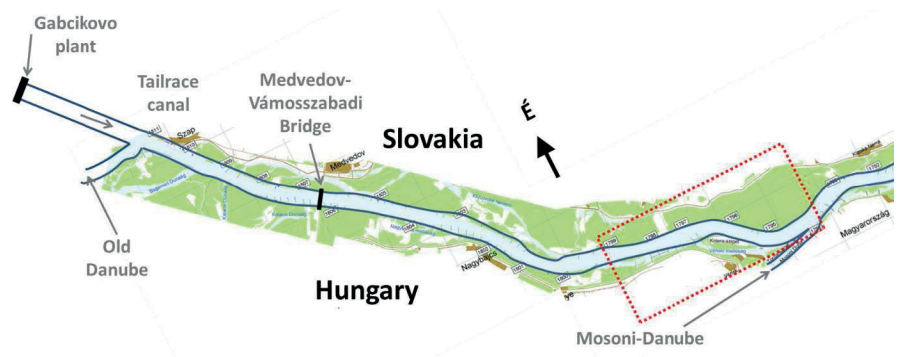

Fig. 1 The sketch of the Danube reach downsream of Gabcikovo hydropower plant

The investigated river reach was a highly dynamic braided channel until the end of the $19^{\text {th }}$ century [4], with a relatively high bedload transport [5]. A unique nature of this river reach is that the planform changes abruptly in a short range from the upper course to the middle course [6]. A sudden decrease of the water slope can be observed (changing from $\sim 40 \mathrm{~cm} / \mathrm{km}$ to $15 \mathrm{~cm} / \mathrm{km}$ ) [7]. Consequently, the sediment transport capacity also significantly decreases, which led to intense aggradation and to the formation of bars, islands and branches [8]. The first significant human measure took place by a river training project of the main Danube channel, between 1886-1896 [9]. The measure had a significant effect on the river morphology. Because of this, at the end of the $19^{\text {th }}$ century, the planform of the river reach became more meandering rather than braided. However, the river planform contained unstable bed forms, e.g. pseudo-bends and surflections [10].

The recently altered morphological processes are caused mainly by two important river training measures [7]. First, the construction of the Gabcikovo dam in 1992 resulted in significant deficit in the sediment supply from upstream reaches. This process led to considerable bed level erosion downstream of the dam, reaching even 2-4 meters. Moreover, the deposition of the eroded bed materials resulted in the formation of further point bars, in the downstream river reach. This process contributed to the further evolution of the Vének ford (Fig. 2) [8]. Second, in order to improve the navigability of the river, groin fields (Fig. 2, continuous dark lines) were constructed aiming at the deepening of the river bed by the increasing flow velocity and anticipated bed erosion. Indeed, these measures had major effects on the local bed morphology, e.g. local scouring and bed material coarsening at the groins heads, and deposition of fine material between and downstream of the groins [11]. Figure 2 shows the navigation map regarding to the examined river reach. The light spots refer to the higher bed levels. Thus, the Vének ford is viewable.

The indicated processes caused spatially and temporally permanently varying flow and morphodynamic conditions, clearly underlining the major role of manmade effects on the river morphodynamics [12]. However, it is expected that the current trends of morphological changes are going to approach a new dynamic equilibrium state [13] reaching a relatively stable bed morphology. Since the morphological features (e.g. longitudinal bed slope, bedload material and volume) have changed significantly, the alteration of the type of the alluvial river pattern (sinuous or meandering river) $[14,15]$ is not obvious, but vital. Thus, the question is, whether the bed level change trends are still in progress, or have already reached a quasi-equilibrium state. The main goal of this research is to predict the potential morphological trends and the potential equilibrium geometry based on bathymetry data, flow measurements, bed material and bedload transport data.

\section{Typical morphological changes after the construction of the upstream power plant (1992)}

Since 1992, the current morphological processes of the study reach are basically influenced by the Gabcikovo hydropower plant. Several research projects were carried out, focusing on the development of the sub-processes of the complex changes.

The lower diagram of Figure 3 shows the bed development in the Danube at the sections between rkm 1813 and rkm 1795. During this period, the effect of the dam resulted intensive degradation downstream of the old Danube and tailrace canal confluence zone (rkm 1813 - rkm 1808). Rákóczi and Sass [16] investigated the morphological effect of the dam, based on field measurements, performed in 1992 October (right before the installation of the Gabcikovo dam), 1993 and 1994. The paper explained in detail the sub-processes, which lead to the

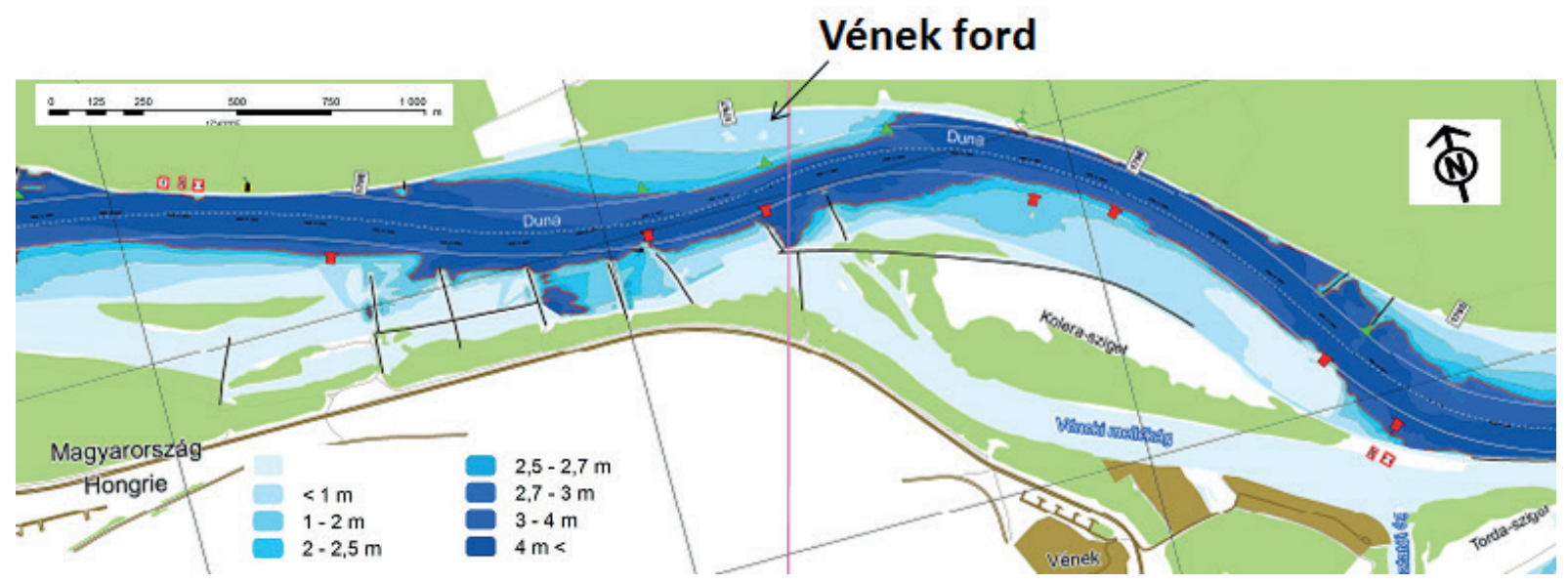

Fig. 2 The navigation map of the study Danube reach and the Vének ford 
complex morphological phenomenon. As the water slope downstream became even lower, the sediment transport capacity suddenly decreased. Thus, the eroded sediments were transported and deposited downstream of the Medvedov-Vámosszabadi Bridge (Figure 3), resulting in the formation of point and side bars. Because of the effect of the selective erosion phenomenon these bed forms typically built up of coarser grains. In the first instance, higher flood waves can cause essential bed changes. However, the selective erosion process leads to the formation of armored bed surface, which contributes to reaching the dynamic equilibrium state. By comparing the bed material samples to the bed geometry changes Rákóczi and Sass supposed, that the bed change process was still in progress, in 1996.

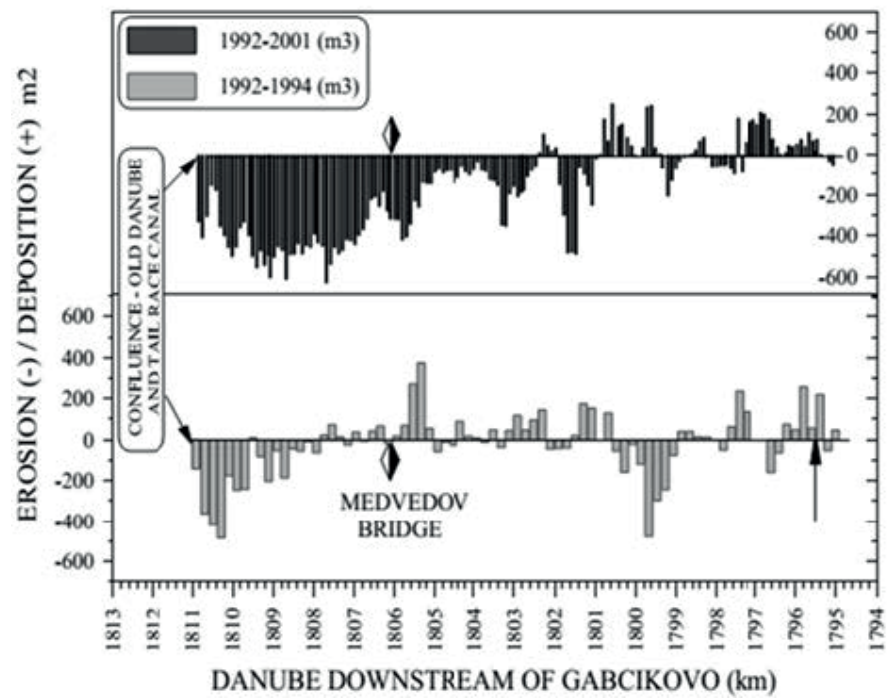

Fig. 3 Morphological changes of the Danube River downstream of Gabcikovo dam [17].

The research work of the Slovakian Water Research Institute detected further bed changes (Fig. 3, top diagram) after 1994, supporting the assumptions of Rákóczi and Sass [17]. Between 1994 and 2001, the erosion section extended downstream and reached $\mathrm{rkm} 1801$. On the other hand, the eroded sediments caused bed level rise and formed bed forms downstream, especially from rkm 1801, which reduced the water level gradient. The research of Holubová [17] also mentioned that the dynamic equilibrium state was not achieved yet, in 2004. In order to reveal bedload dynamics, as a primary indicator of morphodynamics, a subsequent research by Rákóczi [18] aimed at estimating the bedload velocity. It was found that an average particle displacement is around $10 \mathrm{~m} /$ day, which is quite considerable, but realistic. In the absence of sediment supply from the upstream, the bed-load transport results in a significantly slower, but apparent shift of the bars anticipating a durable morphological variation at the bars, such as the Vének ford. At 2004 Rákóczi found [18] that the dynamic equilibrium state was not yet reached.
Holubova et al. [19] published a research on the morphological development of the Hungarian-Slovakian Danube between the installation of the Gabcikovo dam and 2013. The paper pointed out that the significant part of the bed erosion took place until 2006, mainly between rkm 1800 and rkm 1812. The deposition of the eroded sediments is a somewhat lower process [11]. However, Holubova et al. [19] found that aggradation occurred between rkm 1770 and rkm 1800, but considerable bed level rise could not be detected since 2006. Accordingly, the bed level deepening and aggradation were still in progress between 2006 and 2013, but the extent of these morphological processes followed a decreasing trend. This is confirmed by the effect of the historical flood wave in 2013; bed erosion at the downstream part of the Gabcikovo dam and deposition at the lower section occurred, but not in a significant magnitude.

A study [20] of Varga-Lehofer studied the annual morphological changes in the navigational channel of the upperHungarian Danube section, for the period between 2005-2013. The study (see Figure 4) showed that beside the not negligible bed level changes, significant trends (consistent erosion or sedimentation) cannot be observed in the thalweg. The coloring indicates that only local changes took place. It can also be stated that the significant geometric changes were mainly caused by flood waves. During high these high water regimes mainly scouring processes at the tip of the groins, deepening in the narrows and bar formations occurred. These kinds of morphological changes were rather local features than typical trends related to a longer river reach. The research points out that the flood waves might have a different effect on a given river reach. For example, the flood waves in 2006 and 2010 resulted in significant bed deepening in the main stream at the river reach of the Vének ford (between rkm 1796 and rkm 1797). In contrast, the historical flood wave in 2013 caused rather bed level rise around this section. The study notes that although the changes in river bed volume suggest a deepening trend in the main stream of the Danube reach between rkm 1796 and rkm 1799, the authors [20] expect rather a sediment deposition trend since 2010 . 


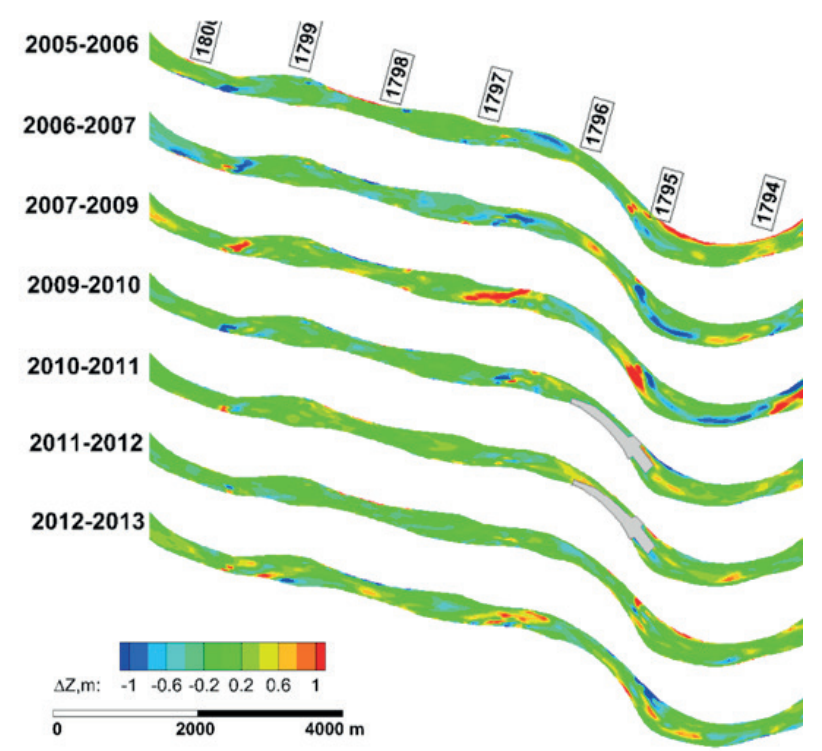

Fig. 4 Bed level changes in the navigational channel between rkm 1794 and rkm 1800 for the period 2005-2013 [20]

Based on the above presented literature, the following findings can be summarized. The considerable bed erosion at the upper part (rkm 1800-1812) and aggradation at the lower reach (1794 - rkm 1800) (Fig. 3) led to the decrease of the water level gradient. Based on the water levels presented by Varga-Lehofer [20], the low flow water surface slope decreased from 23-25 $\mathrm{cm} / \mathrm{km}$ (1984) to $13-15 \mathrm{~cm} / \mathrm{km}$ (2014) between rkm 1812-1792. The erosion capacity is characterized well by the bed shear stress, which can be expressed according to the slope method:

$$
\tau=\rho g h S
$$

in which $\rho$ is the fluid density, $g$ is the gravitational acceleration, $h$ is the water depth, and $S$ is the water surface slope. Accordingly, the erosion and thus the sediment transport capacity depend quasi linearly on the water slope [8]. Since the water level slope decreased significantly during the last 30 years, essential reduction trend in the erosion is expected, this suggests the reaching of the dynamic equilibrium state.

\section{Morphological study of the Vének ford between 1992-2014}

The Vének ford can be found in the examined Danube reach (Fig. 2) at the left bank of the river, between rkm 1796 and rkm 1797. As the study of Varga-Lehofer [20] presented, considerable bed changes occurred in the vicinity of the ford, between rkm 1797 and rkm 1794, but exact trends for the whole reach cannot yet be detected. However, because of the appearance and formation of the ford, the navigation became more and more difficult at this river reach. Therefore, the morphological processes around these bed forms were studied in more details, in order to determine the dominant bed change processes and the potential trends. For this purpose, the cross-sectional bed levels were depicted from the years 1992, 2002, 2006 and 2013 (Fig. 5), related for the transect at rkm 1797.3 (see Fig. 2). The cross-sectional bed geometry measurements were carried out by the North-Transdanubian Water Directorate in Hungary. Based on the figures, the characteristic bed changes can be estimated over 1992 - 2013.

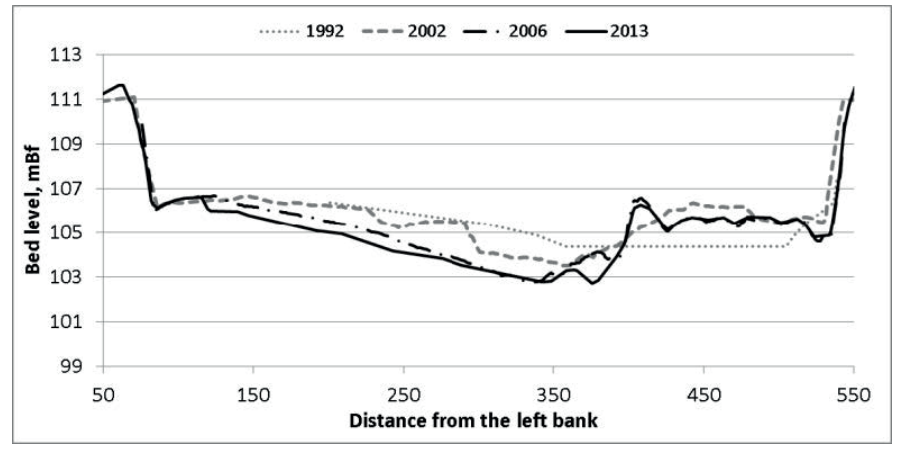

Fig. 5 Cross-section geometries at rkm 1797.3 (Vének ford, upper section), in years 1992, 2002, 2006 and 2013, respectively.

The Vének ford is located at the left bank of the river. Thus, looking at the left part of Figure $5(100-250 \mathrm{~m})$ it turns out that continuous erosion processes occurred at least in the upstream part of the ford, since 1992. The phenomenon can be explained by the deficit in sediment supply caused by the Gabcikovo dam. The investigation of the spatial changes of the ford was 
performed based on the bed level change maps from 20062007, 2007-2009, 2009-2012 and 2012-2014, respectively (Fig. 6).

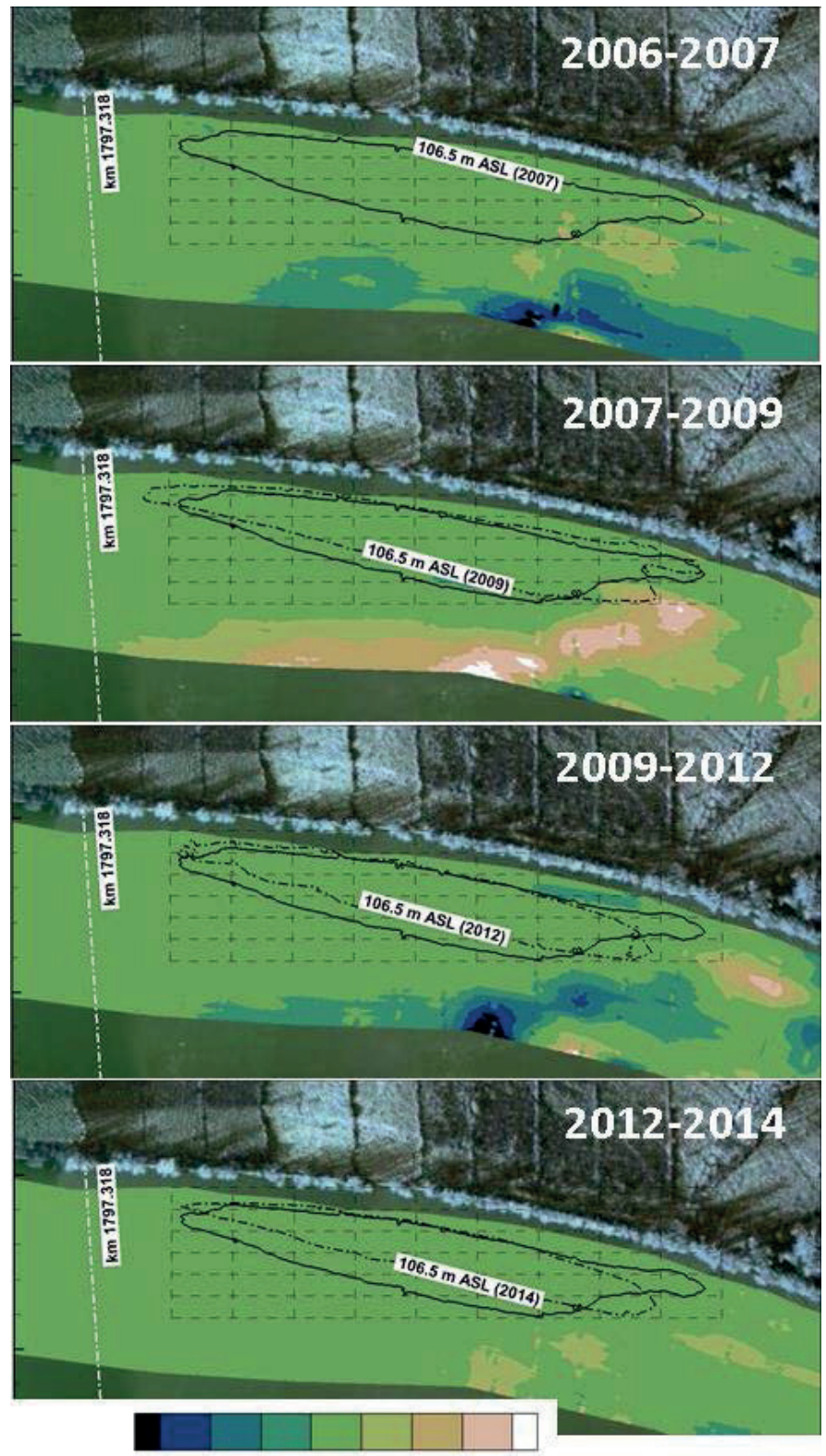

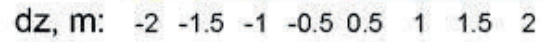

Fig. 6 Bed level difference maps for periods 2006-2007, 2007-2009, 2009 2012 and 2012-2014, respectively. The continuous line shows the $106.5 \mathrm{~m}$ a.s.1. in year 2007 in each figure, while the dotted line indicates the $106.5 \mathrm{~m}$ a.s.1. for to the given year.

It can be seen, that river bed aggradation occurred at the downstream of the ford (right edge of the dotted line, Fig. 6, top two figures) between 2006 and 2007 as well as between 2007 and 2009. Over the same period, the growing of the ford in the upstream direction can also be detected. No remarkable transversal changes can be observed though between 2006 and 2009. From 2009, both longitudinal and transversal reduction of the ford is visible (see Fig. 6, third figure, dotted line). The bar was shortened by $\sim 20 \mathrm{~m}$ at both the upstream and downstream sides. The transverse erosion can also be detected; the ford has narrowed by $15 \mathrm{~m}$ in the average between $2007-2014$.
Despite the fact that the dotted contour line indicates significant spatial decrease of the ford, the bed change maps show that the maximum bed level lowering was only about $0.5 \mathrm{~m}$. These statements are consistent with Fig. 5; the slight incision of the ford can be observed between 2006 and 2013.

\section{Morphological investigation based on flowmeasurements}

In order to gain more detailed insight into the local morphological and hydrodynamic state and processes, field measurements were carried out. A 1-day long field expedition was performed between rkm 1796 and rkm 1800 including the Vének ford, in 2013 July [21].

Within the measurement campaign, the flow conditions and bed geometry was mapped using a so-called acoustic Doppler current profiler (ADCP) (WorkHorse Rio Grande $1200 \mathrm{kHz}$ ) in both fix and moving modes. The operating principle and different application fields of ADCPs are explained, for example, by [22]. During the fix boat measurements, the boat was anchored in a given location for at least 180 seconds. At those locations, bed material samples were also taken by a drag-bucket sampler. Thus, the composition of the bed material could be determined by laboratory analysis of the physical samples.

At the study river reach, the average depth at mean flow is around $5 \mathrm{~m}$ and the mean discharge is around $2000 \mathrm{~m}^{3} / \mathrm{s}$. The measurement was conducted right after the historical flood wave at the discharge of $1500 \mathrm{~m}^{3} / \mathrm{s}$ at low flow regime. The following figure shows the discharge time series for a 2-year-long period, indicating date of the measurement by the dashed line.

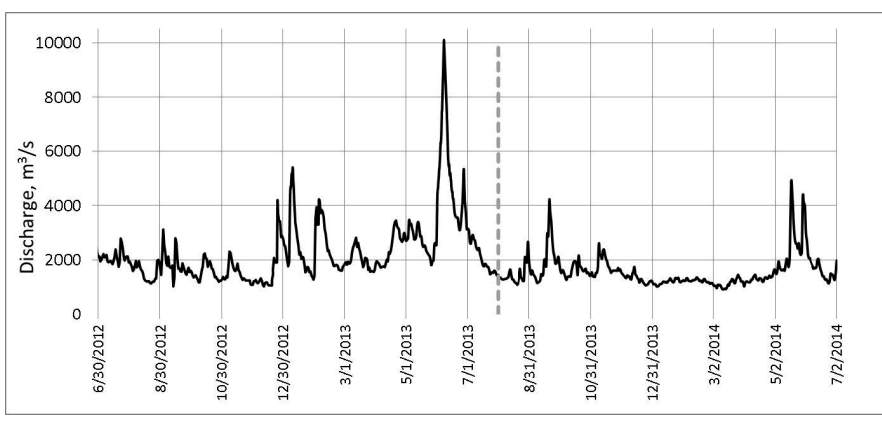

Fig. 7 Discharge time series at rkm 1801 for the period 2012 July - 2014 June.

As Rákóczi [25] introduced through a number of cross-sections of the Danube River, the combined analysis of the crosssectional bed geometry and the cross-sectional grain-size distributions of the bed material can provide valuable information regarding the local morphological status of the river. In Figure 8 the contour map indicates bed levels, while the circles on the plots indicate the local $d_{90}$ values of the bed material, derived from the bed material analysis. The larger and lighter the circle, the coarser the bed material. The darker spots refer to the lower bed levels, thus the main stream can be observed. 


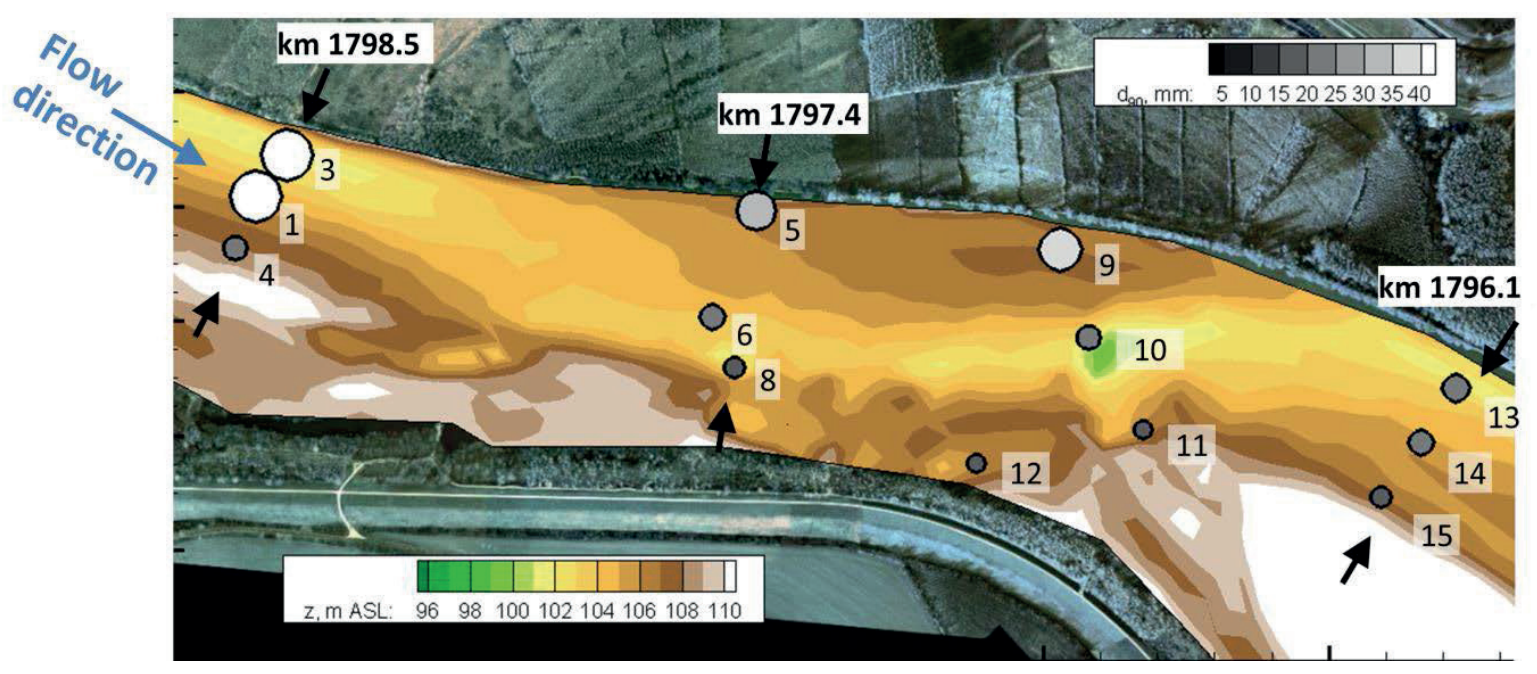

Fig. 8 Spatial distribution of $d_{90}$ values of bed material samples.

Usually, the coarsest bed material along a river transect is expected in the thalweg, i.e. at the deepest part of the section. Indeed, this character can be detected in cross-sections at rkm 1796.1 and $\mathrm{rkm}$ 1798.5, respectively. In the remaining two cross-sections, however, the coarsest sample was found at the left bank side, which in fact characterizes the Vének ford. This phenomenon can be explained by the selective erosion process [11], i.e. if the bedload particles arrive in a place with lower bed shear stress than upstream, the coarser and maybe the finer grains find a more stable place. Thus, the transport velocity of the grains decreases and, in case of larger gravels, can actually stop. Finally, the trapped particles can form dunes, bars or islands, where each grain size can be found (the largest gravels might have the highest percentage). In turn, in the thalweg, the flow with higher sediment transport capacity does not let the finer particles to settle, therefore they most likely cannot be found in the bed material. Consequently, the bed material contains rather coarser gravels, leading to the development of bed armor.

Figure 9 shows the cross-sectional bed levels and the points, where bed material samples were taken from at rkm 1798.5. The related grain-size distributions can be seen in Figure 10. As the bed geometry suggests, thalweg shifts to the left bank. The coloring of Fig. 8 clearly indicates the intensive narrowing of the channel here. The consequent flow acceleration results in an increasing bed shear, which explains why the bed sample nr. 3 consist of the coarsest grains (Fig. 10). Apparently, this part of the bed is armored, since the sand is almost completely absent here (Fig. 10, solid line). The resistance of the bed surface is most probably high, because the historical flood wave (which happened a month before the measurement campaign) was not able to break up the armor. Bed sample nr. 1 is located a little farther from the thalweg. The sediment transport capacity is lower, which leads to the appearance of finer sand particles in the bed material. The shape of the grain-size distribution curve suggests that this point is in dynamic equilibrium state, i.e. the sediment supply and the eroded sediments are in equilibrium. Sample nr. 4 contains almost coarse sand, without significant amount of gravel or silt. Based on the following statements it can be stated that although the points are in different morphological phases, no significant morphological changes are expected.

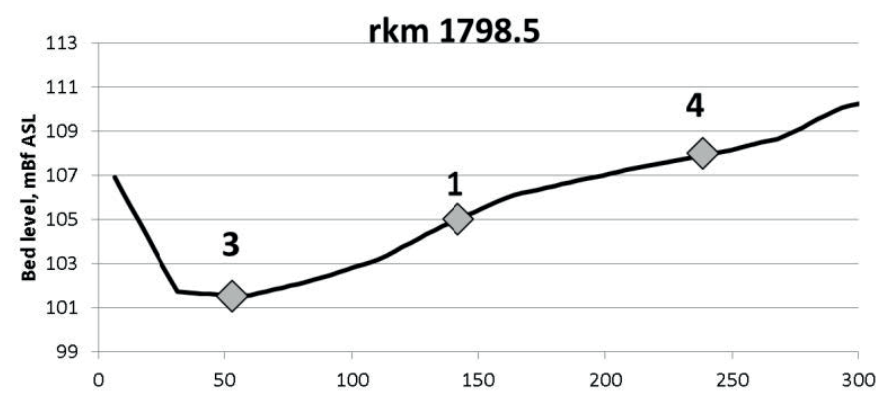

Fig. 9 Cross-secional bed levels at rkm 1798.5.

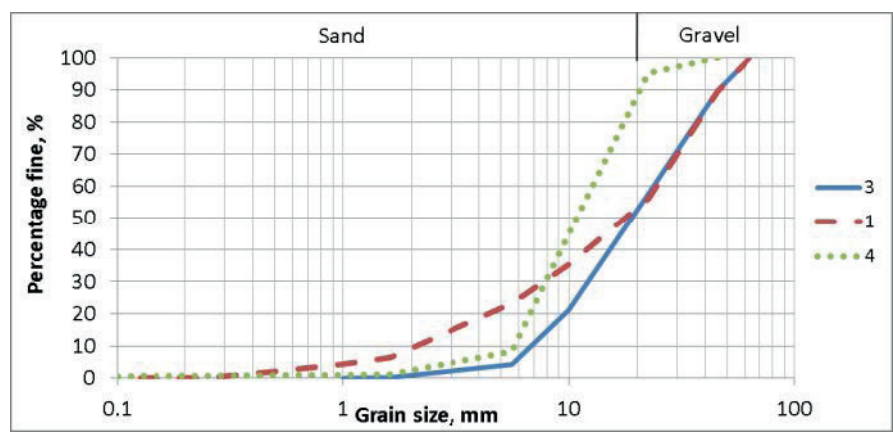

Fig. 10 Grain size distribution curves at rkm 1798.5.

Figure 11 shows the cross-sectional bed levels involving an upper segment of the Vének ford (sampling point nr. 5). Figure 8 indicates the shifting of the thalweg to the right bank. Therefore, close to the left bank, the flow has a lower erosion capacity. The coarser sediment grains arriving from upstream can therefore be trapped here, and the transport velocity of the finer grains also decreases. The grain size distribution of this point (Fig. 12, solid line) enhances this phenomenon, i.e. the rate 
of the coarser grains is significantly higher that of finer particles. Since the larger grains are not trapped in the main stream (Fig. 8), the rate of the gravel fractions is lower. Apparently, the transport capacity at sampling point nr. 8 is high enough to wash out all the finer $(<2 \mathrm{~mm})$ sands. Since the shapes of the three grain size distribution curves are quite similar, moreover, they almost overlap each other, the cross-section seems to be in dynamic equilibrium state and so none of the points indicate bed armor development or siltation.

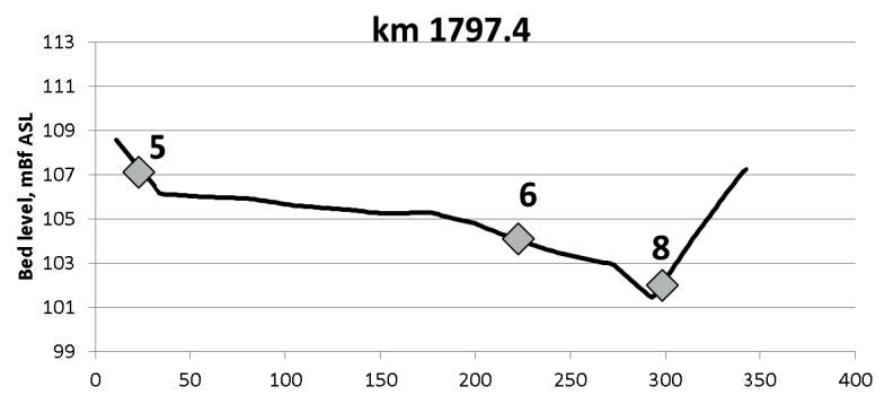

Fig. 11 Cross-secional bed levels at rkm 1797.4.

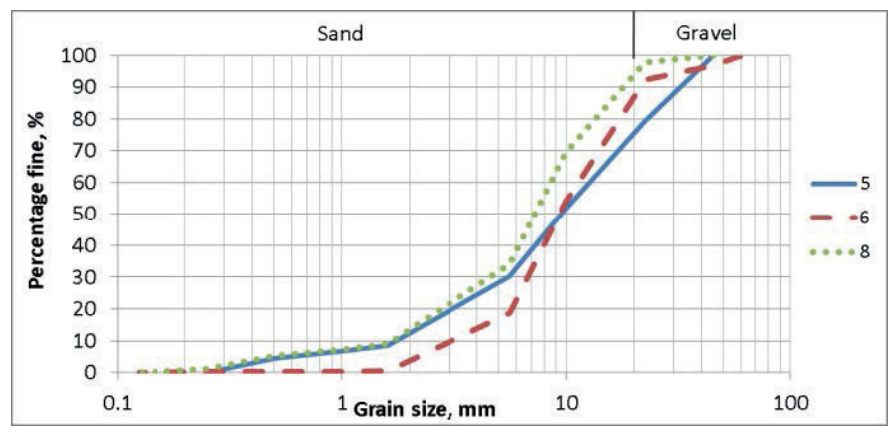

Fig. 12 Grain size distribution curves at rkm 1797.4.

Finally, the cross-section downstream of the Vének ford was analyzed. As Figure 8 suggests, the thalweg is shifted to the left bank at this location. The coarsest bed material sample was, however, not taken from the left bank but rather from the center of the section (see points nr. 13 and 14 in Fig 14). Similarly to the previously analyzed cross-section, the similar and coincident grain-size distribution curves (Fig. 14), containing all sizes of the fractions, characterizes this part of the river. It can be concluded that this cross-section also represents dynamic equilibrium state.

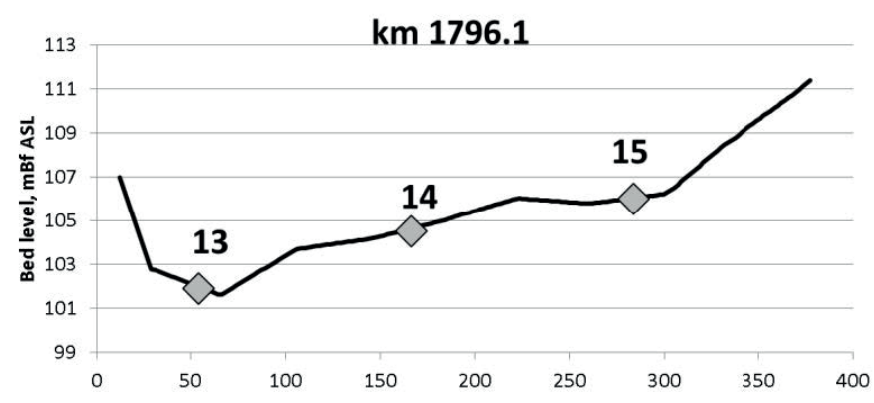

Fig. 13 Cross-secional bed levels at rkm 1796.1.

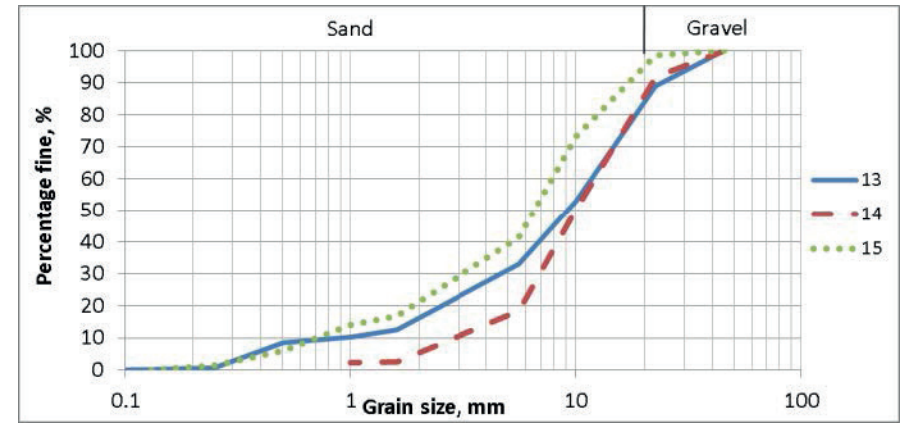

Fig. 14 Grain size distribution curves at rkm 1796.1

An essential part of the field measurement was the determination of the local bed shear stress values. As Kim et al. [23] reported in their study, several methods exist to estimate the bed shear stress as a function of the flow conditions. Here, the bed shear stress was estimated based on the turbulent wall law [24] using the time averaged vertical velocity profiles obtained from the fixed boat ADCP measurements and spatio-temporal averaged velocity profiles from the moving boat measurements. In the latter case a moving averaging of a $40 \mathrm{~m}$ wide window was performed on the raw velocity data. The turbulent wall law equation is:

$$
U(z)=\frac{u_{*}}{\kappa} \ln \left(\frac{z}{z_{0}}\right)
$$

where $U(z)$ is the horizontal velocity, $u_{*}$ is the shear velocity, is constant von $\operatorname{Karman}()$, and $z_{0}$ is the zero-velocity level above the bed.

Accordingly, the bed shear velocity value can be expressed using the equation of the logarithmic function fitted to the averaged velocity profile (e.g. [11]). Finally, the bed shear stress can be quantified as:

$$
\tau=\rho u_{*}^{2}
$$

where $\tau$ is the bed shear stress and $\rho$ is the density of the water.

The interaction between the near-bed flow conditions and the bed material could be well assessed by comparing the $d_{90}$ grain size values and the local bed shear stress values at the measured points (Fig. 15). The different notations of the points indicate the typical location of the sampling point in the bed, such as thalweg, bank or gravel bar. A general and logical tendency can be observed, indicating that the increasing bed shear stress characterizes a coarser bed surface. This statement in fact refers to the selective erosion phenomenon. There are, however, three points indicated by circles, which do not match the general tendency. Based on the comparison of the squares against the triangles and circles it can be seen that at the same shear values the coarsest bed materials belong to the points of the Vének ford. This finding supports the statement that the forming and coarsening of fords can be explained by the trapping of the coarser gravels transported from upstream. 
The other separated single point indicated by a circle refers to a possible armour breakup, since a quite low $d_{90}$ value belongs to a high bed shear stress. The other two circles with higher $\left(>6 \mathrm{~N} / \mathrm{m}^{2}\right)$ bed shear stresses suggest bed armoring, as the corresponding bed material at these locations is rather coarse, $d_{90}>40 \mathrm{~mm}$.

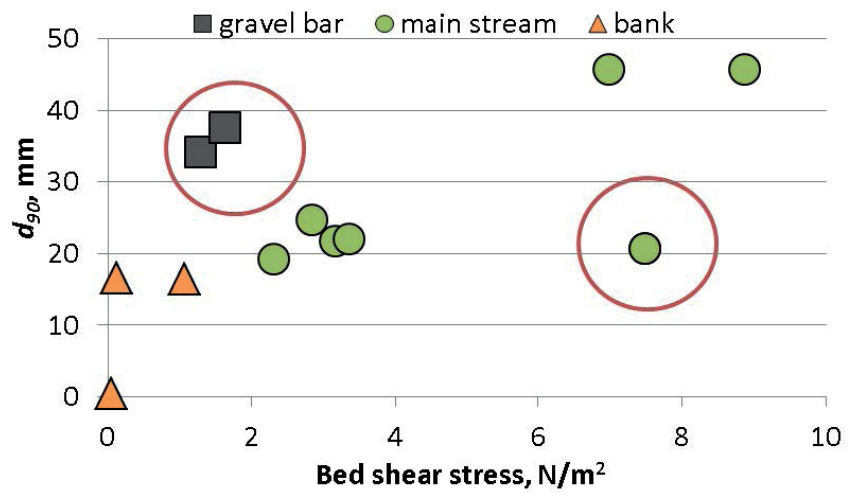

Fig. $15 d_{90}$ values of the bed material samples in the function of the related local bed shear stress values.

Based on the moving boat ADCP measurements, cross-sectional bed shear stress distributions could also be estimated according to Eq. (2) and (3). As mentioned before, the instantaneous velocity data was first smoothed with a $40 \mathrm{~m}$ wide moving averaging and the logarithmic curve was fitted onto the filtered velocities. This in fact means a spatial and temporal averaging of the velocities. The estimated bed shear stress values are plotted in Fig. 16 by dotted lines. The solid white lines on the same plots indicate estimated bed shear stress values derived from flood measurements. The related moving boat ADCP surveys were performed during at the peak of the historical flood wave in 2013, at a flow discharge of $\sim 10000 \mathrm{~m}^{3} / \mathrm{s}$.

In the most upstream section, the highest bed shear values are shifted to the left bank during low water which can be explained by the narrowing of the channel as mentioned above (see again Fig. 8). During the flood, however, the channel widens and the highest bed shear moves to the centerline of the river. It is also notable, that despite the cca. five times higher flow discharge, the maximum values are nearly the same. Due to the armored left part of the channel, local bed changes could be caused by the flood rather along the right side of the channel. In the cross-section located at rkm 1797.4, the bed shear stress values during the flood were respectively higher at the thalweg than during low flow, increasing from 1-3 N/m² to 5-10 $\mathrm{N} / \mathrm{m}^{2}$. At the right part of the cross-section, the bed shear stress distribution likely refers to local effects, e.g. the extreme value of $\sim 20 \mathrm{~N} / \mathrm{m}^{2}$ might be resulted by the highly turbulent flow generated by the groin. This result also suggests that rather only local bed changes are expected during floods. The effect of the groins can be observed in the most downstream cross-section, too. The extreme peaks in the shear distribution are caused by the groin in case of the low flow (dotted line) and caused by the steering effect of the downstream island during the flood. However, the shear values are consequently higher during the flood at the right part. It causes the resuspension of fine particles from the otherwise dead flow zones, e.g. behind the groins. The flood wave causes significant bed shear stress increase at the left side of the cross-section, where the Vének ford is located. Despite the quite coarse bed material at the ford, the higher erosion capacity lead to the erosion on the downstream end of the bar, as discussed above.

\section{Bedload regime investigation based on field measurements}

The North-Transdanubian Water Directorate in Hungary carries out regular bedload transport measurements from the Medvedov-Vámosszabadi Bridge (rkm 1806) since 1998. During the period of 1998 - 2015, 66 measurement campaigns were performed under different flow regimes characterized with a discharge range of $949 \mathrm{~m}^{3} / \mathrm{s}$ and $4670 \mathrm{~m}^{3} / \mathrm{s}$. According to the regular method seven samples are taken from the cross-section by the same method and equipment (modified Károlyi bedload

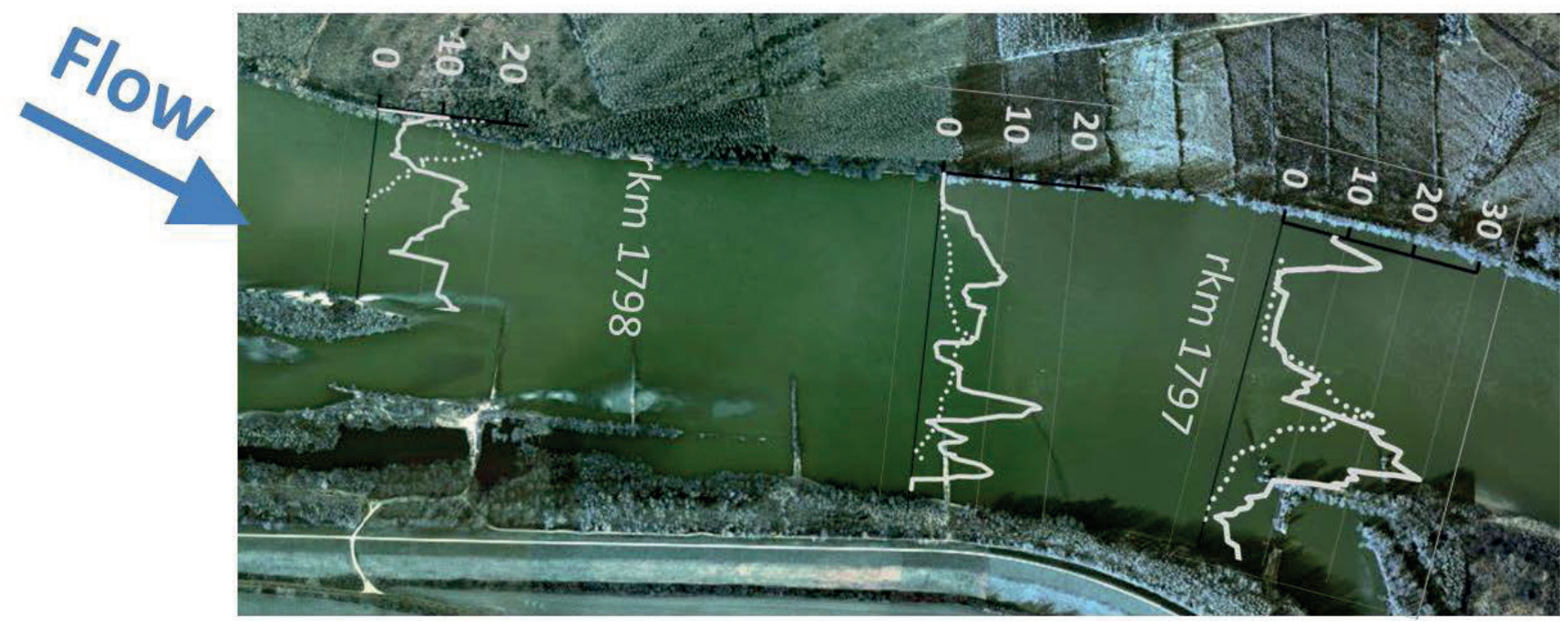

Fig. 16 Cross-sectional bed shear stress distributions during the peak of the 2013 historical flood wave (white line) and at mean flow (dotted white line). 
sampler [7]). The sampling interval is 15 minutes. Based on the results of the 18 year long data collection, the bedload regime, which represents the upstream end of the study river reach at the Vének ford, can be analyzed.

Figure 17 shows the measured bedload discharge values versus the flow discharge. The values are separated for consecutive 6 years.

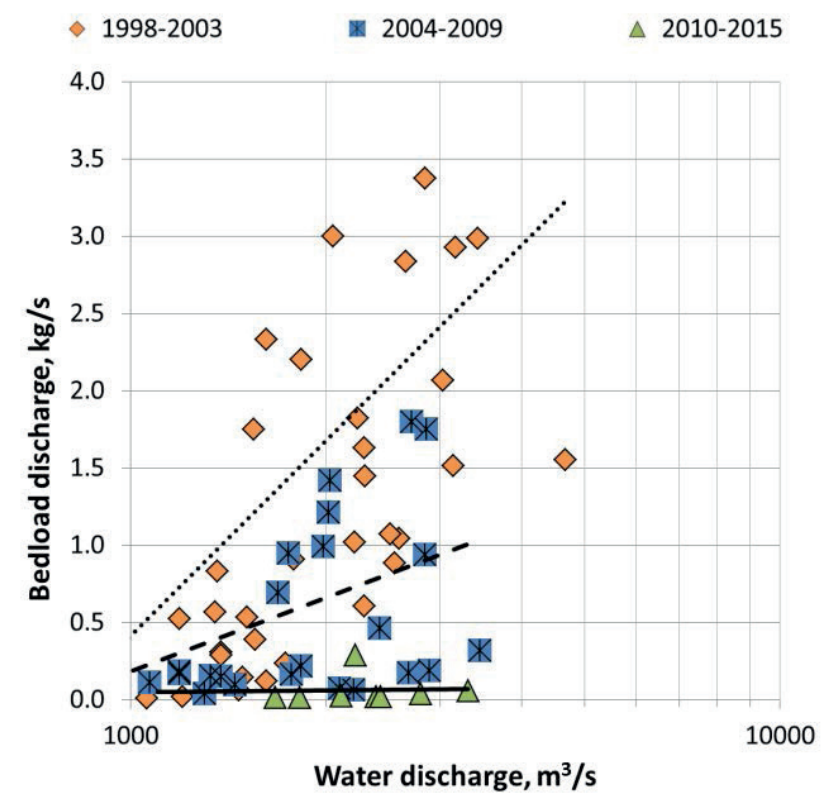

Fig. 17 Bedload rating curves for three time periods, 1998-2003 (dotted line, diamonds), 2004-2009 (dashed line, stars) and 2010-2015 (line, triangles), respectively.

The rating curves were fitted separately for the three indicated periods. A significant scattering of the points can be observed (Fig. 17), however, a clear tendency is also detectable, showing a considerable decrease of the bedload transport in time. For instance, the bedload rate at medium flow discharge $\left(\sim 2000 \mathrm{~m}^{3} / \mathrm{s}\right)$ drops from 1.7 to $0.1 \mathrm{~kg} / \mathrm{s}$, i.e. with 94 $\%$. This phenomenon suggests that the previously recognized erosion between the Gabcikovo hydroelectric power plant and Medvedov-Vámosszabadi Bridge (rkm 1819 - 1806) became less significant.

Based on these findings, the following assumption can be made: along the eroded reach (between rkm 1812-1800) bed armor developed and a consequent stable river bed. Furthermore, due to the decreased amount of bedload transport from the upstream sections the aggradation process at the study site became also less important, enhancing the equilibrium conditions. As a matter of fact, the decreasing trend of the bedload discharge at the study river reach was also reported by Holubová et al. in 2015 [19]. In that study a completely different approach was used compared to the data assessment method introduced here, as a 1D sediment transport model was applied for the morphological investigation of the Danube. Their results also show a clear decreasing tendency in the long-term bedload transport.
As a matter of fact, the decreasing trend of the bedload discharge at the study river reach was also reported by Holubová et al. in 2015 [19]. In that study a completely different approach was used compared to the data assessment method introduced here, as a 1D sediment transport model was applied for the morphological investigation of the Danube. Their results also show a clear decreasing tendency in the long-term bedload transport.

\section{Conclusions}

The morphological features of the study reach in the upper Hungarian section of the Danube River (downstream of the Gabcikovo hydroelectric power plant) have significantly changed during the recent decades. Based on the results of this study it can be stated that a significant decrease of the bedload discharge took place. This process and the considerable reduction of the water level gradient phenomenon [17] suggest that the river planform of the river was changed [15]. This sort of morphological variation can also be justified by the water gradient criterion of Lane [26] according to which, the decrease of the water level slope initiates a straight meandering transition. Moreover, the recent decreasing trends in the water level gradient and in the bedload discharge contribute to the formation of stable and incised river channel. However, this kind of planform change caused by anthropogenic impacts is not a unique phenomenon, similar process could be recognized e.g. in River Dráva in the 19-20th centuries [27]. Based on these conclusions, reduction in the development of gravel bars and less diverse cross-sections, in terms of geometry, are expected. This is consistent with the findings concerning the stable river reaches, in Chapter 3.

It can be stated, the study river reach is close to a dynamic equilibrium condition. Slight morphological changes in the future can be expected though, such as the slow abrasion tendencies at the Vének ford during mainly floods accompanied by minor bed level rise in the main channel. However, the authors assume that these future variations in the morphology will rather be the result of local processes (e.g. scouring process, silting up behind groins, etc...) instead of morphological changes effecting the whole river reach.

Besides the assessment of field data of different spatial and temporal scales, such as the ones introduced in this study, an alternative manner to analyze and predict future bed changes is the $3 \mathrm{D}$ computational modelling. The computational flow models coupled with sediment transport models have already been applied for the Hungarian Danube and showed promising results [28, 29, 30, 31]. Moreover, recent improvements of the sediment transport modeling techniques, by e.g. combining two sediment formulas and applying them in the same model at the same time at zones of different morphological characteristics [32] can even more contribute to the reliable prediction of future bed geometry changes. Furthermore, with the utilization of numerical tools the impact assessment of planned river restoration measures can also be performed. 


\section{Acknowledgements}

We acknowledge the funding of the second author from the János Bolyai fellowship of the Hungarian Academy of Sciences. This work was partly supported by MTA TKI of the Hungarian Academy of Sciences.

\section{References}

[1] Hankó, Z., Starosolszky, Ö., Bakonyi, P. "Megvalósíthatósági tanulmány a Duna környezetének és hajózhatóságának fejlesztésére.”. (Danube Environmental and navigation Project, Feasibility Study) Vizügyi Közlemények, 78(3), pp. 291-315. 1996. (In Hungarian)

[2] Rákóczi, L. “A Duna-meder sorsa Szap és Szob között.”. (Destiny of the Danube channel between Szap and Szob.) Vizügyi Közlemények, 82(2), pp. 262-280. 2000. (In Hungarian)

[3] Goda, L. "A Duna gázlói Pozsony-Mohács között.”. (Shallows of the River Danube between Pozsony, Bratislava and Mohács.) Vizügyi Közlemények, 77(1-2), pp. 71-102. 1995. (In Hungarian)

[4] Farkas-Iványi, K., Guti, G. "The effect of hydromorphological changes on habitat composition of the Szigetköz floodplain.”. Acta Zoologica Bulgarica, S7, pp. 117-121. 2014.

[5] Schumm, S. A. "Evolution and response of the fluvial system, sedimentologic implications.”. SEPM Special Publication, No. 31, pp. 19-29. 1981.

[6] Hankó, Z., Alföldi, L., Starosolszky, Ö. “A Felső-Duna és a Szigetköz hidrológiai jellemzőinek megváltozása a dunacsúni vízlépcső üzembe helyezése nyomán.”. (Changes in the hydrological regime of the upper Hungarian Danube and the Szigetköz area upon putting the Cunovó River Barrage into operation). Vizügyi Közlemények, 76(1-2), pp. 8-59. 1994. (In Hungarian)

[7] Baranya, S., Józsa, J., Török, G. T., Ficsor, J., Mohácsiné Simon, G., Habersack, H., Haimann, M., Riegler, A., Liedermann, M., Hengl, M. “A Duna hordalékvizsgálatai a SEDDON osztrák-magyar együttmüködési projekt keretében.”. (Introduction of the joint Austro-Hungarian sediment research under the SEDDON ERFE-project) Hidrológiai Közlöny, 95(1), pp. 41-46. 2015. (In Hungarian)

[8] Rákóczi, L. “A Duna hordalékjárása.”. (Sediment load conditions of River Danube) Vizügyi Közlemények, 75(2), pp. 128-146. 1993. (In Hungarian)

[9] Ihrig, D., “A Magyar vizszabályozás története.”. (History of the Hungarian water regulation). Vízdok, Budapest. 1973. (In Hungarian)

[10] Baranya, S., Goda, L., Józsa, J., Rákóczi, L. “Complex hydro- and sediment dynamics survey of two critical reaches on the Hungarian part of river Danube.". IOP Conference Series: Earth and Environmental Science, 4(1), Paper 012038. 2008. https://doi.org/10.1088/1755-1307/4/1/012038

[11] Török, G. T., Baranya, S., Rüther, N., Spiller, S. "Laboratory analysis of armor layer development in a local scour around a groin.”. In: RIVER FLOW 2014: 7th International Conference on Fluvial Hydraulics (River Flow). Lausanne, Switzerland, Sep. 03-05. 2014. Boca Raton FL: CRC Press - Taylor and Francis Group, 2014. pp. 1455-1462.

[12] Farkas-Iványi, K., Trájer, A. "The influence of the river regulation on the aquatic habitats in river Danube, at the Bodak branch system, Hungary and Slovakia.". Carpathian Journal of Earth and Environmental Sciences, 10(3), pp. 235-245. 2015.

[13] Hankó, Z. "Gondolatok a Duna Szap és Szob közötti szakaszának fejlesztéséröl.". (Considerations related to the development of the Danube reach between Szap and Szob ) Vizügyi Közlemények, 82(2), pp. 285-299. 2000. (In Hungarian)

[14] Dey, S. "Fluvial Processing Meandering and Braiding". In: "Fluvial Hydrodynamics: Hydrodynamic and Sediment Transport Phenomena." Chapter 9. (Dey, S.) pp 529-562. Springer Berlin Heidelberg. 2014.https:// doi.org/10.1007/978-3-642-19062-9_9
[15] Schumm, S. A., Dumont, J. F., Holbrook, J. M. "Active Tectonics and Alluvial Rivers." Cambridge University Press, Cambridge, New York, Melbourne. 2000. https://doi.org/10.1017/s0016756800454415

[16] Rákóczi, L., Sass, J. “A Felső-Duna és a Szigetközi mellékágak mederalakulása a dunacsúni duzzasztómü üzem behelyezése után.”. (Changes of the channel of the Hungarian Upper Danube and of the side river arms of the Szigetköz upon putting the Dunacsúny I. river barrage into operation) Vizügyi Közlemények, 77(1), pp.46-75. 1995. (In Hungarian)

[17] Holubová, K., Capeková, Z., Szolgay, J. "Impact of hydropower schemes at bedload regime and channel morphology of the Danube River.". In: River Flow, 2004. (Greco, M., Carravetta, A., Della Morte, R. (Eds)), Balkema Publisher. 1, 135-142. 2004. https://doi.org/10.1201/b16998-18

[18] Rákóczi, L. “A Duna Szap-Gönyü közötti szakaszának hajózási viszonyait javító beavatkozások vizsgálata.”. Expert report, Budapest. 2004.

[19] Holubová, K., Comaj, M., Lukác, M., Mravcová, K., Capeková, Z., Antalová, M. "Final report in DuRe Flood project.”. Bratislava. 2015.

[20] Varga-Lehofer, D. “A felső-magyarországi Duna morfológiai változásainak elemzése.”. (Morphological investigation of the upper Danube in Hungary) BSc thesis, Budapesti Müszaki és Gazdaságtudományi Egyetem, Budapest. 2014. (In Hungarian)

[21] Török, G. T. “Terepi adatgyüjtés, adatfeldolgozás, numerikus modellmegalapozása.”. (Field data collection, post processing, establishing of numerical modeling) Expert report in SEDDON project. 2014. (In Hungarian)

[22] Baranya, S. "Three-dimensional analysis of river hydrodynamics and morphology." PhD. thesis, Budapest University of Technology, Budapest. 2009.

[23] Kim, S. C., Friedrichs, C. T., Maa, J. P. Y., Wright, L. D. "Estimating bottom stress in tidal boundary layer from Acoustic Doppler velocimeter data.". Journal of Hydraulic Engineering, 126(6), pp. 399-406. 2000. https://doi.org/10.1061/(ASCE)0733-9429(2000)126:6(399)

[24] Schlichting, H., Gersten, K. “Boundary layer theory.” 2000. 10.1007/9783-642-85829-1_2

[25] Rákóczi, L. "Selective Erosion of Noncohesive Bed Materials.”. Geografiska Annaler. Series A. Physical Geography, 69(1), pp. 29-35. 1987. https://doi.org/10.2307/521364

[26] Lane, E. W. "A study of the shape of channels formed by natural streams flowing in erodible material." United States Army Engineer Division, Missouri River Division, Corps of Engineers, Omaha, Nebraska. 1957.

[27] Kiss, T., Balogh, M. "Characteristics of Point-Bar Development under the Influence of a Dam: Case Study on the Dráva River at Sigetec, Croatia.”. Journal of Environmental Geography, 8(1-2), pp. 23-30. https://doi.org/10.1515/jengeo-2015-0003

[28] Baranya, S., Józsa, J. "Flow analysis in river Danube by field measurement and 3D CFD turbulence modeling.". Periodica Polytechnica Civil Engineering, 50(1), pp. 57-68. 2006.

[29] Baranya, S., Józsa, J., "Numerical and laboratory investigation of the hydrodynamic complexity of a river confluence.". Periodica Polytechnica Civil Engineering, 51(1), pp. 3-8. 2007. https://doi.org/10.3311/pp.ci.2007-1.01

[30] Török, G. T., "Vegyes szemcseösszetételü folyómedrek numerikus vizsgálata.”. (Numerical investigation of non-uniform river bed) Hidrológiai Tájékoztató, pp. 22-24. 2013. (In Hungarian)

[31] Török, G. T., Baranya, S., Rüther, N. "Three-dimensional numerical modeling of non-uniform sediment transport and bed armoring process.". In: 18th Congress of the Asia \& Pacific Division of the International Association for Hydro-Environment Engineering and Research 2012. Jeju, South-Korea, Aug. 19-23, 2012. Paper 0816.

[32] Török, G. T., Baranya, S., Rüther, N., “3D CFD modeling of local scouring, bed armoring and sediment deposition.”. Water, 9(1), Paper 56, p. 23. 2017. https://doi.org/10.3390/w9010056 